\title{
ISLAMIC INSCRIPTIONS
}





\section{ISLAMIC INSCRIPTIONS}

Sheila S. Blair 
(C) Sheila S. Blair, I 998

Edinburgh University Press

22 George Square, Edinburgh

Transferred to digital print 2008

Designed and typeset in Trump Medieval by Fionna Robson

Printed and bound by CPI Antony Rowe, Eastbourne.

A CIP record for this book is available from the British Library

ISBN 0748609032

The right of Sheila S. Blair to be identified as author of this work has been asserted in accordance with the Copyright, Designs and Patents Act 1988. 